\title{
ІНФОРМАЦІЯ
}

\section{ВИМОГИ ДО ПУБЛІКАЦІЙ У ВІСНИКУ КИЇВСЬКОГО НАЦІОНАЛЬНОГО ЛІНГВІСТИЧНОГО УНІВЕРСИТЕТУ \\ Серія Педагогіка та психологія}

Видання індексується

Copernicus http://journals.indexcopernicus.com/passport.php?id=24783920

Google Scholar http://scholar.google.com.ua/

Фахова реєстрація у ВАК України:

Реєстрація - постанова Президії ВАК України від 11.10.2000 року №1-03/8, Бюлетень ВАК України № 6, 2000 p.

Перересстрація - додаток № 8 до наказу Міністерства освіти і науки України від 21.12.2015 р. №1328

Редакція приймає і розглядає неопубліковані раніше матеріали - наукові статті, методичні розробки, аналітичні огляди, рецензії монографій / підручників тощо, які відповідають фаху журналу (збірника наукових праць).

Редколегія збірника здійснює внутрішнє та зовнішнє рецензування рукописів статей, поданих до опублікування. У разі негативної рецензії стаття може бути повернена автору на доопрацювання або відхилена з таких причин: відсутність актуальності, низький науковометодичний рівень, недостатня практична цінність методичних розробок, недотримання вимог щодо укладання анотації (Abstract) англійською мовою.

Редакція перевіряє статтю на плагіат, результати якого повідомляються автору.

Редакція здійснює наукове і літературне редагування статті та погоджує відредагований варіант із автором.

Якщо стаття має позитивний відгук рецензента, відповідає вимогам МОН (ДАК) України, міжнародних індекс-баз і редакційній політиці збірника, автор отримує від редакції лист про підготовку і видання статті, а також її розміщення та поширення в мережі Інтернет.

У рамках редакційної політики збірника наукових праць "Вісник Київського національного лінгвістичного університету. Серія Педагогіка та психологія" редколегія послідовно дотримується міжнародних видавничих стандартів COPE Code of Conduct, затверджених COP (Committee on Publication Ethics).

\section{Загальна характеристика наукової статті}

Наукова стаття містить виклад проміжних або кінцевих результатів наукового дослідження, висвітлює конкретне окреме питання за темою дисертації чи наукового дослідження, фіксує науковий пріоритет автора, робить іï матеріал надбанням фахівців.

Наукова стаття подається до друку в завершеному вигляді відповідно до чинних вимог ДАК МОН України (Див. Бюлетені ВАК України № 1, 2003; № 2, 2008).

Перелік обов'язкових елементів статті:

* Постановка проблеми у загальному вигляді та іï зв'язок із важливими науковими чи практичними завданнями.

- Аналіз останніх досліджень і публікацій, в яких започатковано розв'язання цієї проблеми і на які спирається автор. 
• Виділення невирішених раніше частин загальної проблеми, яким присвячується означена стаття.

* Формулювання мети статті (постановка завдань).

* Виклад основного матеріалу дослідження 3 повним обгрунтуванням отриманих результатів.

* Висновки з цього дослідження і перспективи подальших розвідок у цьому напрямку.

При написанні статті необхідно дотримуватись певних рекомендацій:

* назва статті має відбивати іiі головну ідею, думку (якомога менше слів);

* слід уникати стилю наукового звіту чи науково-популярної статті;

* недоцільно ставити риторичні запитання; мають переважати розповідні речення;

* цитати в статті використовуються дуже рідко; необхідно зазначити основну ідею, а після неї в дужках указати прізвище автора, який уперше іiі висловив;

* посилання на інших науковців подаються на початку статті, основний обсяг статті присвячується викладу власних думок;

* для підтвердження достовірності своїх висновків і рекомендацій не слід наводити висловлювання інших учених, оскільки це свідчить, що ідея дослідника не нова, була відома раніше і не підлягає сумніву;

* необхідно дотримуватися офіційної транслітерації українських літер латиницею;

* стаття повинна мати просту структуру (без поділу на розділи і підрозділи).

Мови публікації - українська, англійська, іспанська, німецька, французька та східні (китайська, японська)

Обсяг статті - 10-12 сторінок 3 таблицями, схемами та малюнками.

Обсяг рецензії - 3-6 сторінок.

Обсяг хроніки - 3-4 сторінки.

\section{Структура статті}

1. УДК (універсальна десяткова класифікація).

2. Назва статті.

3. Прізвище та ініціали автора /співавторів.

4. Електронна адреса

5. Місця роботи і навчання.

6. Дата надходження. Дата прийняття до друку.

6. Анотації та ключові слова українською, російською (обсяг 800-900 знаків та 5-6 ключових слів після кожної анотації відповідними мовами) та англійською мовами. Анотація англійською мовою (Abstract) є стислим викладом змісту статті, iї реферуванням. Тому вона має бути укладена відповідно до вимог міжнародних наукометричних баз і переважати за обсягом українсько- та російськомовну анотації (1500-1700 знаків). Крім того, вона має містити такі структурні елементи: Introduction, Purpose, Methods, Results, Conclusion.

Зразок оформлення початку статті

УДК 811.111’253:81’23

\section{СПЕЦИФІКА ПСИХОЛОГІЧНИХ МЕХАНІЗМІВ МОВЛЕННЄВОЇ ДІЯЛЬНОСТІ ПЕРЕКЛАДАЧА У ПИСЬМОВОМУ ДВОСТОРОННЬОМУ ПЕРЕКЛАДІ}

Максименко Л. 0.<smiles>[Mg][Ca]</smiles>

Київський національний лінгвістичний університет

Дата надходження ... . Рекомендовано до друку ... . 
Анотація. Стаття грунтується на результатах аналізу робіт зарубіжних і вітчизняних учених, присвячених проблемам психології перекладу. Розглянуто своєрідність процесу письмового перекладу як особливого виду мовленнєвої діяльності. Проаналізовано існуючі наукові концепції щодо рівнів психологічних механізмів та етапів перекладацької діяльності. Грунтуючись на результатах проведеного аналізу, нами було визначено специфіку функціонування психологічних механізмів у письмовому двосторонньому перекладі. Наголошується на необхідності враховувати психологічні особливості цього виду мовленнєвої діяльності у процесі навчання, оскільки знання закономірностей сприйняття, осмислення, різних видів пам'яті, уваги, механізмів антиципації і випереджуючого синтезу допомагають викладачеві обирати раціональні методи та прийоми, а також забезпечують керування перекладацькою діяльністю студентів.

Ключові слова: письмовий двосторонній переклад, мовленнєва діяльність, психологічні механізми, етапи перекладацької діяльності.

Максименко Л. А. Киевский национальный лингвистический университет

Специфика психологических механизмов речевой деятельности переводчика в письменном двустороннем переводе

Аннотация. Статья основывается на результатах анализа работ зарубежных и отечественных ученых, посвященных проблемам психологии перевода. Рассматривается своеобразие процесса письменного перевода как особенного вида речевой деятельности. Проанализированы существующие научные концепции относительно уровней психологических механизмов и этапов переводческой деятельности. В соответствии с результатами проведенного анализа определена специфика функционирования психологических механизмов в письменном двустороннем переводе. Указывается на необходимость учитывать психологические особенности этого вида речевой деятельности во время обучения, поскольку знание закономерностей восприятия, осмысления, разных видов памяти, внимания, механизмов антиципации и упреждающего синтеза помогают преподавателю выбирать рациональные методы и приёмы, а также обеспечивают управление переводческой деятельностью студентов.

Ключевые слова: письменный двусторонний перевод, речевая деятельность, психологические механизмы, этапы переводческой деятельности.

\section{Maksymenko L. Kyiv National Linguistic University}

Peculiarities of psychological mechanisms of translator's speech activity in bilingual translation

Abstract. Introduction. Researchers have shown that psychological nature of language and speech activity can be illuminated by all communication aspects study which also defines communication rules and laws implemented in translation activity. Translation process psychological interpretation allows going beyond the linguistic concept of translation which involves comparison and analysis. Purpose. To determine the features of translation process as a specific kind of speech activity; to identify the peculiarities of psychological mechanisms as well as the characteristics of their functioning at the stages of bilingual translation activity. Methods. Reviewing the studies on psychological problems of translation conducted abroad and in Ukraine with the view to analyzing existing scientific concepts of levels of psychological mechanisms of translation and stages for translation activity. Results. This study revealed that knowledge of psychological characteristics and mechanisms of translation gained while learning has a positive impact on the development of bilingual translation skills. General psychological mechanisms of translation such as perception, thinking, different types of memory, etc. are the intelligence structure components. That is why their development facilitates the personal development as a whole. The purposeful development of text comprehension mechanisms helps to improve students' bilingual translation skills and develop their native language. As a result, the quality of text translation in native and foreign languages is improving. In addition, the development of attention, anticipation, synthesis facilitates mastering other communicative language activities. Conclusion. To sum up, it was found that an understanding of the concept that translation should be viewed as a speech and thinking activity will provide an insight into the way in which a translator's psychological mechanisms can be trained. The defined peculiarities of psychological mechanisms of translation will serve as a basis for determining the professional translator's skills and as a prerequisite for developing bilingual translation teaching methods.

Key words: bilingual translation, speech activity, psychological mechanisms of translation, stages of translation activity. 
Текст статті ...

6. Текст статті має містити такі елементи (виділяються жирним шрифтом):

a) постановка проблеми та іï зв'язок із важливими науковими чи практичними завданнями (у тексті статті Постановка проблеми.);

б) аналіз останніх досліджень і публікацій, в яких започатковано розв'язання досліджуваної проблеми і на які спирається автор, виділення невирішених раніше частин загальної проблеми, котрим присвячена означена стаття (у тексті статті Аналіз останніх досліджень і публікацій.);

в) формулювання мети статті, постановка завдання (у тексті статті Мета статті ...);

г) виклад основного матеріалу дослідження з повним обгрунтуванням отриманих наукових результатів (у тексті статті Основні результати дослідження.);

д) висновки і перспективи подальших розвідок у даному напрямку (у тексті статті Висновки і перспективи подалыших розвідок.).

Посилання на використану літературу та джерела у тексті оформлюються відповідно до AРА стилю (American Psychological Association) Style.

\section{7. Література.}

Список літератури має складатися із двох блоків:

1) ЛІТЕРАТУРА (для оформлення списку джерел використовується АРА стиль. Інформація щодо міжнародного стандарту АРА $є$ на сайті НБУВ: http://nbuv.gov.ua/node/929. Також див.: APA Citation Style (https://www.library.cornell.edu/research/citation/apa). Оформити цитування відповідно до стилю АРА можна на сайті онлайнового автоматичного формування посилань: http://www.citationmachine.net/apa/cite-a-book; http://www.bibme.org/apa/bookcitation/manual.

2) REFERENCES (повністю повторює літературу українською чи російською мовами, іншомовні джерела; щодо іноземних бібліографічних джерел, крім англомовних, то текст посилання наводиться англійською мовою або транслітерується латиницею).

Для транслітерації латиницею україномовних і російськомовних текстів рекомендуємо скористатися відповідними програмами 3 такими режимами доступу: http://translit.ru та http://litopys.org.ua/links/intrans.htm

\section{Вимоги до оформлення рукописів:}

- стаття подається у електронному вигляді (file.doc редакції Word для Windows версія 6.0, 7.0) без автоматичних переносів слів разом з одним примірником друкованого тексту;

- відцентрована назва публікації друкується великими літерами жирним шрифтом (розмір шрифту 14), під нею двома рядками нижче в центрі звичайними літерами прізвище та ініціали автора жирним шрифтом (розмір шрифту 14), рядком нижче - назва навчального закладу курсивом (світлий) (розмір шрифту 14);

- анотації і ключові слова подаються шрифтом 10 Times New Roman через 1,5 інтервали без відступу;

- основний текст рукопису друкується через 1,5 інтервали без переносів шрифтом 12 Times New Roman, поля ліворуч, вгорі, внизу, праворуч - 1,5 см. Відступ абзацу $-1,25$ см. Чітко диференціюються тире (-) та дефіс (-);

- не допускається заміна знака апострофа ( ') іншими знаками;

- спеціальні шрифти, символи та ілюстрації додаються окремими файлами;

- сторінки рукопису нумерують олівцем на звороті;

- ілюстративний матеріал подається курсивом; елементи тексту, які потребують виділення, підкреслюються; значення слів тощо беруться у лапки (“...”); упродовж усього тексту використовується лише такий тип лапок; 
- ЛІТЕРАТУРА друкується жирним шрифтом великими літерами. Нижче в підбір до тексту подається без відступу занумерований перелік цитованих робіт (довідники включно) в алфавітному порядку у ручному режимі. За необхідністю надається список джерел ілюстративного матеріалу, оформлений аналогічно, якому передує назва джерела ілюстративного матеріалу;

- підрядкові виноски не допускаються.

- роздрукований текст статті;

\section{У редакцію необхідно представити:}

- електронний варіант статті;

- довідку про автора (-ів) на окремому аркуші та окремим файлом (прізвище, ім'я та по батькові повністю), науковий ступінь, вчене звання, місце роботи і навчання (аспірантам додатково зазначити - прізвище, ім'я та по батькові, науковий ступінь, учене звання, місце роботи і посаду наукового керівника), посада, контактні телефони, поштова адреса (з поштовим індексом) та електронна адреса;

- наукову рецензію доктора або кандидата наук з відповідної спеціальності з рекомендацією статті до друку; підпис рецензента має бути завірений печаткою установи.

Аспірант і здобувач наукового ступеня кандидата наук надає рецензію кандидата або доктора наук; докторант і здобувач наукового ступеня доктора наук - наукову рецензію доктора наук, кандидат наук - кандидата наук, доцента або провідного фахівця.

За фактичний матеріал (статистичні дані, формули, дати, цитати, власні назви тощо) несе відповідальність автор.

Подані до редколегії матеріали не повертаються.

Пакет документів відправлясться за адресою:

Редколегія збірника наукових праць "Вісник Київського національного лінгвістичного університету. Серія Педагогіка та психологія"

вул. Велика Васильківська, 73, кім. 305

м. Київ, 03150, Україна

Електронна версія статті та довідка про автора надсилаються за адресою

knlupedvisnyk@gmail.com

Редакційна колегія 